\title{
THE ESTIMATION IN SEA-WATER SOLUTIONS OF MICRO-QUANTITIES OF MERCURY IN THE PRESENCE OF COPPER BY MEANS OF DITHIZONE
}

\author{
By H. Barnes, B.A., B.Sc., \\ Chemist, The Corrosion Committee, Iron and Steel Institute \\ (From the Marine Station, Millport)
}

\section{INTRODUCTION}

With the development of leaching methods (Ketchum, Ferry, Redfield \& Burns, 1945; Harris, I945) for the study of anti-fouling compositions and the increased interest in the toxicity of copper and mercury to marine organisms, it has become desirable to have a moderately rapid method for the estimation of mercury in the presence of copper ions. Frequently, in these solutions, the copper is in large excess; commonly, leachates contain from 300 to $900 \mu \mathrm{g}$. of copper and up to $50 \mu \mathrm{g}$. of mercury per litre of sea water. Mercury in the absence of copper may be readily estimated in these concentrations by the use of dithizone, and the tentative curves of Wichmann (1939) suggest that it is completely extracted even at $p \mathrm{H} 2 \cdot 0$. However, according to these curves copper is also partially extracted at this acidity. The two most recent methods for the determination of mercury by dithizone in the presence of copper are those of Laug \& Nelson (1942) and Reith \& van Dijk (see Sandell, I944). The former workers separate the mercury from the copper by shaking an acid potassium bromide solution with the mixed dithizonates. The mercury is thereby transferred to the aqueous phase and is determined by a mixed colour method after bringing the $p \mathrm{H}$ of solution to 6.0. The method of Reith \& van Dijk is much longer and involves regulated extraction of the mixed dithizonates. In addition, Hubbard (1940) has separated the two metals with a dithizone technique by shaking the combined dithizonates with sodium thiosulphate solution; the mercury is transferred to the aqueous phase and after destruction of the thiosulphate with permanganate and of the latter with hydroxylamine, the mercury may be estimated in the aqueous layer. The method outlined below is simpler; it depends upon the slow rate of reaction of a chloroform solution of dithizone with copper and the complex forming action of potassium cobalticyanide with copper salts.

\section{GENERAL}

The mixed colour method has been used, transmittancies being determined with the Spekker Photoelectric Absorptiometer using blue-green filters (Ilford 603) and a I cm. cell. 
The experimental work has been carried out in a darkened room and all transmittancy measurements made as rapidly as possible after extraction. This precaution is particularly necessary when working with mercury solutions, for the decomposition of the mercury dithizonate seems to be catalysed by the presence of small traces of copper salts. The instrument is usually set at 0.700 against pure chloroform; the differences between the drum reading for the dithizone blank and the unknown is, over the range used, directly proportional to the mercury content of the solution. Such a procedure is more reliable when working over long periods (since the instrument may be reset for each reading of the unknown) than the alternative of setting the instrument against the dithizone blank at the beginning of the series and leaving it so set. Using the strength of dithizone and volumes given below, Io $\mu \mathrm{g}$. of mercury per litre corresponds approximately to a difference in the drum reading of 0.025 . Assuming that the drum may be read in the lower regions to 0.003 (one-quarter of a division) the accuracy of the method cannot be greater than $\pm \mathrm{I}-2 \mu \mathrm{g}$. of mercury per litre. When using the Spekker Absorptiometer it has been the practice to set the instrument and then rapidly take an approximate reading of the unknown. The instrument is then reset and, with the shutter closed, the drum is moved into the previous position. The unknown is now placed in position and the final adjustment of the drum made rapidly. All these precautions are necessary when working with concentrations indicated, i.e. 5-50 $\mu$ g. of mercury per litre. With the method outlined below manipulative losses are, however, negligible. A working curve is constructed using mercuric chloride in sea water.

Concentrations are expressed throughout in $\mu \mathrm{g}$. or mg. per litre of solution finally extracted.

It must be stated that strict adherence to the volumes indicated is essential, i.e. $100 \mathrm{ml}$. solution and $10 \mathrm{ml}$. dithizone. The amount of mercury present in the $100 \mathrm{ml}$. of solution actually extracted is $\mathrm{I}-\mathrm{IO} \mu \mathrm{g}$.

The sea water was freshly collected for each day's work, and filtered before use.

\section{Reagents}

Nitric acid-A.R. $25 \% \mathrm{v} / \mathrm{v}$.

Hydroxylamine hydrochloride-A.R. $4 \%$ aqueous solution.

Dithizone-this is purified by repeated extraction with ammonia (see Sandell, 1944). The stock solution (I g./1.) is stored in a refrigerator and is diluted 40-50 times just before use, giving a final strength of approximately $20 \mathrm{mg}$./1.

Chloroform-B.P. grade.

Potassium cobalticyanide-freshly prepared solution containing Iog. per Ioo $\mathrm{ml}$. distilled water.

\section{The Stability of Dithizone in Chloroform Solution}

In view of the difficulties experienced by some workers, the stability of the reagent during long runs of mercury determinations in sea-water solutions 
has been checked. In many months' work no significant trouble has been experienced when using the conditions outlined above. Thus in fifty determinations taken at random from a fortnight's work, some taken morning and afternoon with the same solution, some being blanks and others from solutions containing copper and mercury both together and alone, the determinations being carried out in triplicate or duplicate (and in part by two observers), the variation in Spekker reading of replicates was equivalent in three instances to $2 \mu \mathrm{g}$. mercury per litre and in the remainder to $\mathrm{I} \cdot 0 \mu \mathrm{g}$. mercury per litre. The $p \mathrm{H}$ of the extracted solutions varied from $\mathrm{I} \cdot 56$ to 4.87 (glass electrode). No change was found in the strength of dithizone taken direct from the burette during a morning's work.

\section{The Rate of Extraction of Copper by Dithizone Solutions}

Wichmann's tentative curves (1939) suggest that copper is not completely extracted until a $p \mathrm{H}$ of 5.0 is reached. Greenleaf (1942) has pointed out that copper is more difficult to extract at $p \mathrm{H} 2.0$ with dithizone (carbon tetrachloride solution) than other metals, and that the amount of copper extracted is related to the amount of dithizone in excess; extraction was complete with no excess dithizone at $p \mathrm{H} 2.0$ and almost complete at $p \mathrm{H} \mathrm{I} \cdot 0$ with $100 \%$ excess dithizone. Laug \& Nelson (1942) also noticed that copper is extracted only slowly by chloroform solutions of dithizone at $\mathrm{pH} \mathrm{I} \cdot \mathrm{O}$. Sandell (I937) states that using carbon tetrachloride solutions of dithizone the extraction of copper $(3-20 \mu \mathrm{g}$.) is complete with $30-40 \mathrm{sec}$. vigorous shaking. However, using a working curve of pure copper sulphate the results were low.

It would appear from the foregoing that copper is much more rapidly removed as dithizonate when a carbon tetrachloride solution of the reagent is used. The use of chloroform solutions in an attempt to eliminate the interference in the extraction of mercury seemed, therefore, to be more promising.

That the rate of extraction of copper by chloroform solutions of dithizone is slow, even when large amounts of copper are present, is indicated by Table I. In all these experiments the volumes of sea water and reagents used were

\section{TABLE I}

Sea-water solution at $p \mathrm{H} \mathrm{I} \cdot 43 \pm 0 \cdot 05$. Total volume extracted $\mathrm{roO} \mathrm{ml}$.

\begin{tabular}{|c|c|c|c|}
\hline \multirow{2}{*}{$\begin{array}{l}\text { Time of } \\
\text { shaking } \\
\text { in min. }\end{array}$} & \multicolumn{3}{|c|}{ Spekker reading } \\
\hline & $3 \mathrm{mg} . \mathrm{Cu} / 1$. & $6 \mathrm{mg} . \mathrm{Cu} / 1$. & I5 mg. $\mathrm{Cu} / 1$. \\
\hline I & 0.418 & 0.410 & 0.350 \\
\hline 2 & 0.402 & 0.357 & 0.293 \\
\hline 4 & 0.355 & 0.345 & 0.227 \\
\hline IO & 0.297 & 0.210 & 0.077 \\
\hline I5 & 0.247 & - & - \\
\hline 25 & 0.158 & - & - \\
\hline
\end{tabular}

similar to those when working with a solution containing $0-50 \mu \mathrm{g}$. mercury per litre final concentration. The procedure was as follows. Sufficient nitric acid was added to the copper solution in sea water, contained in a $250 \mathrm{ml}$. separating 
funnel to bring the $p \mathrm{H}$ to the required value when the volume was made up to $100 \mathrm{ml}$. I $\mathrm{ml}$. of $4 \%$ hydroxylamine hydrochloride was then added and the solution shaken. Io $\mathrm{ml}$. of dithizone were added and the funnel shaken for a given time. After allowing the two layers to separate and inserting a roll of filter paper in the stem of the funnel, sufficient of the chloroform layer was run off to fill a $\mathrm{I} \mathrm{cm}$. cell and the transmittancy of the solution measured. The $p \mathrm{H}$ of the aqueous layer was then measured using the glass electrode.

In the above experiments the dithizone was clearly not in excess (it has been suggested that the formula for the dithizonate is $\mathrm{CuDz}_{2}$, so that $30 \mu \mathrm{g}$. of dithizone are equivalent to about $3.7 \mu \mathrm{g}$. of copper). In the above, approximately $200 \mu \mathrm{g}$. of dithizone were present. However, even with excess dithizone and a higher $p \mathrm{H}$ value the copper is still extracted comparatively slowly by chloroform solutions of the reagent as is indicated by Table II.

\section{TABLE II}

Sea-water solution at $p \mathrm{H} 4 \cdot 20 \pm 0 \cdot 09$. Total volume extracted $100 \mathrm{ml}$. $7 \cdot 5 \mu \mathrm{g}$. copper present per litre.

$\begin{array}{cc}\text { Time of shaking (min.) } & \text { Spekker reading } \\ \text { I } & 0.360 \\ 4 & 0.217 \\ \text { I0 } & 0.206 \\ \text { I5 } & 0.200\end{array}$

Table I indicates that even with $300 \mu \mathrm{g}$. of copper present and shaking for I min. the equivalent of only I $\mu \mathrm{g}$. of mercury (assuming all the mercury to be taken up) would be extracted. The rate of extraction of copper with chloroform solutions is in marked contrast to that for carbon tetrachloride solutions of the reagent. The figures of Table III indicate the much more rapid rate of extraction even at comparatively low copper concentrations and low $p \mathrm{H}$ values.

\section{TABLE III}

Sea-water solution-dithizone in carbon tetrachloride. Total volume extracted, roo $\mathrm{ml}$.

\begin{tabular}{|c|c|c|c|}
\hline \multirow{3}{*}{$\begin{array}{l}\text { Time of } \\
\text { shaking } \\
\text { min. }\end{array}$} & \multicolumn{3}{|c|}{ Spekker reading } \\
\hline & \multicolumn{2}{|c|}{$p \mathrm{H}$ I.I6 } & \multirow{2}{*}{$\begin{array}{r}p \mathrm{H} 2 \cdot 80 \\
26 \mu \mathrm{g} . \mathrm{Cu} /\end{array}$} \\
\hline & $52 \mu$ g. $\mathrm{Cu} / 1$. & $25 \mu \mathrm{g} . \mathrm{Cu} / 1$. & \\
\hline I & 0.410 & 0.465 & 0.445 \\
\hline 2 & 0.396 & 0.440 & 0.436 \\
\hline 5 & 0.378 & 0.440 & 0.440 \\
\hline
\end{tabular}

\section{The Rate of Extraction of MERcury}

Before proceeding further it was established that shaking for I min. was adequate to ensure 'complete' extraction of the mercury. (By 'complete', nothing is assumed with regard to completion of mercury-dithizone reaction but only that equilibrium has been attained under the specific conditions.) 
Using the above procedure the results given in Table IV were obtained, indicating that a shaking time of I min. is adequate.

\section{TABLE IV}

Sea-water solution. Total volume extracted $100 \mathrm{ml} . \quad 55 \mu \mathrm{g}$. mercury $/ \mathrm{l}$.

Spekker reading

\begin{tabular}{|c|c|c|c|}
\hline \multirow{2}{*}{$\begin{array}{l}\text { Time of } \\
\text { shaking } \\
\text { min. }\end{array}$} & \multirow[b]{2}{*}{$p \mathrm{H} \mathrm{I} \cdot 42 \pm 0.02$} & \multicolumn{2}{|c|}{$p \mathrm{H} \mathrm{I} \cdot 20 \pm 0.02$} \\
\hline & & (a) & (b) \\
\hline I & $\overline{0.252}$ & 0.354 & 0.353 \\
\hline $\begin{array}{l}2 \\
4\end{array}$ & $\begin{array}{l}0.353 \\
0.350\end{array}$ & $0.35^{2}$ & 0.354 \\
\hline I0 & 0.350 & 0.352 & 0.360 \\
\hline
\end{tabular}

THE INTERFERENCE OF COPPER IN THE ESTIMATION OF MERCURY

The tentative curves of Wichmann suggest that the $p \mathrm{H}$ in the estimation of mercury should not be reduced below I .0 . Since the mercury can be extracted by $\mathrm{I}$ min. shaking at $p \mathrm{H} \mathrm{I} \cdot 2$ (see above) the interference due to moderate amounts of copper was next investigated. With the procedure outlined the results shown in Table $\mathrm{V}$ were obtained.

\section{TABLE V}

Sea-water solution at $p \mathrm{H} \mathrm{I} \cdot 2$. Total volume extracted $100 \mathrm{ml} .55 \mu \mathrm{g}$. mercury/l.

Copper added $\mu \mathrm{g} . / 1$.

$\circ$
290
570
860
1150
2300
6900

Mercury found $\mu \mathrm{g} . / 1$.
Error (positive) $\mu \mathrm{g} . / 1$.

$\begin{array}{lr}55 & 0 \\ 55 & 0 \\ 58 & 3 \\ 58 & 3 \\ 62 & 7 \\ 63 & 8 \\ 90 & 35\end{array}$

That the extent of this interference depends in some measure on the strength of the dithizone and possibly on the relative amounts of copper and mercury present is shown by the figures of Table VI, which were obtained using dithizone one-fifth the usual strength and only if $\mu \mathrm{g}$. of mercury per litre.

\section{TABLE VI}

Sea-water solution at $p \mathrm{H}$ I.20. Total volume extracted $100 \mathrm{ml}$. II $\mu \mathrm{g}$. mercury $/ 1$.

Copper ad.
$\mu \mathrm{g} . / 1$.
$\circ$
290
570
860
1150
2300
3450

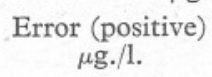

II
14
15
17
17
24
29

0
3
4
6
6
I3
I8

It is clear that the interference with moderate amounts of copper is small and somewhat irregular. 


\section{The Cobalticyanide Method}

The interference due to copper may, then, be reduced by the reduction in time of shaking and the acidity. Elimination of the residual interference would seem possible by a reduction in the copper concentration by means of a complex forming substance-stable in acid solution. Potassium cobalticyanide appears to fulfil these conditions and the following technique has proved satisfactory.

\section{Procedure}

To $92^{1} \mathrm{ml}$. of the solution contained in a $250 \mathrm{ml}$. separating funnel add $2 \mathrm{ml}$. of nitric acid. After shaking add I ml. of hydroxylamine hydrochloride solution and repeat the shaking. Add $5 \mathrm{ml}$. of cobalticyanide solution, shake and allow to stand Io min. Add Io ml. of dithizone solution and shake for I min. at approximately four shakes per second. After the chloroform layer has settled, insert a roll of filter paper in the stem of the funnel, draw off the required volume of chloroform into a $\mathrm{I} \mathrm{cm}$. cell and determine its transmittancy immediately.

Results

The results of a series of mercury determinations in the presence of varying amounts of copper are shown in Table VII.

\section{TABLE VII}

Total volume extracted $100 \mathrm{ml}$. Concentration in $\mu \mathrm{g}$./1.

\begin{tabular}{cllll}
$\mathrm{Cu}$ present mg./1. & \multicolumn{1}{c}{ I. $\mathrm{Cu}$} & $5.0 \mathrm{Cu}$ & $5 \cdot 0 \mathrm{Cu}$ & $6.9 \mathrm{Cu}$ \\
$\mathrm{Hg}$ present $\mu \mathrm{g} . / 1$. & $22 \mathrm{Hg}$ & II $\mathrm{Hg}$ & $55 \mathrm{Hg}$ & $55 \mathrm{Hg}$ \\
Found $\mathrm{Hg}$ & 22 & II & 53 & 55 \\
& 22 & II & 56 & 56 \\
& 22 & I2 & 55 & 55 \\
& 21 & I2 & $55-$ & 55 \\
& 22 & IO & - & 55 \\
& 22 & I0 & - & 56
\end{tabular}

Table VIII gives the results of the analysis of a series of solutions prepared by an independent worker, the copper and mercury contents being unknown to the analyst.

It should be noted that above about I mg. of copper per litre of solution the addition of the cobalticyanide produces a precipitate; this does not affect the estimation except in so far as it necessitates careful drawing off of the chloroform layer after the dithizone extraction. Occasionally a rather high return has been obtained when working at $\mathrm{r} \cdot 0 \mathrm{mg}$./1. of copper, and this may be attributed to the difficulty of separating the small amount of precipitate

1 This volume was chosen from a consideration of the intended application: the effect of changes in volumes of solution and dithizone on the method has not yet been studied. 


\section{TABLE VIII}

Total volume extracted $100 \mathrm{ml}$. Concentration in $\mu \mathrm{g} . / 1$.

$\begin{array}{ccc}\text { Cu present } & \text { Hg present } & \text { Hg found } \\ \text { II50 } & 47 & 48 \\ 3450 & 99 & 99 \\ 6900 & 71 & 71 \\ 0 & 99 & 98 \\ 6900 & 25 & 24 \\ 4600 & 47 & 47 \\ 500 & 33 & 34 \\ 500 & 88 & 89 \\ \text { 1000 } & 59 & 62\end{array}$

formed under these conditions. In one run when this was experienced, a further addition of $500 \mu \mathrm{g}$. was made to an aliquot portion after the addition of the cobalticyanide so that a distinct precipitate was then produced; the positive error was then eliminated.

It need hardly be emphasized that dithizone technique requires care and experience. The results quoted above were obtained after considerable experience and continuous work on the present method. However, using the method as outlined above, the results shown in Table IX were obtained by an analyst without previous experience of the procedure.

\section{TABLE IX ${ }^{1}$}

Sea-water solution at $p \mathrm{H} \mathrm{I} \cdot 20$. Total volume extracted, IOO ml. Concentrations in $\mu \mathrm{g} . / 1$.

$\begin{array}{cccc}\text { Hg present } & \text { Cu present } & \text { Hg found } & \text { Error } \\ \text { II } & 0 & \text { IO } & -\mathrm{I} \\ 30 & \text { I250 } & 31 & +\mathrm{I} \\ 36 & 5000 & 32 & -4 \\ 4 \mathrm{I} & \mathrm{I} 250 & 42 & -\mathrm{I} \\ 50 & 310 & 49 & -\mathrm{I} \\ 52 & 3000 & 50 & -2 \\ 60 & 940 & 60 & 0 \\ 65 & 6300 & 65 & 0 \\ 74 & 630 & 72 & -2 \\ 88 & 3750 & 87 & -\mathrm{I} \\ 91 & 1000 & 89 & -2 \\ \text { I03 } & 930 & 105 & +2\end{array}$

${ }_{1}$ Acknowledgement is made to Dr Stubbings of the Metallurgical Laboratory, Emsworth, in whose department the results quoted in the table were obtained.

\section{The Estimation of Copper and Mercury}

It may, on occasions, be desirable to determine the copper and mercury in the same solution, and the method given below may then be used.

\section{Reagents}

As for the mercury estimation with the following additions:

Citric acid- $25 \% \mathrm{w} / \mathrm{v}$ in distilled water.

Ammonium hydroxide-(A.R.) sp.gr. 0.880.

Sodium diethyldithiocarbamate- $0 . \mathrm{I} \%$ filtered aqueous solution. 


\section{Procedure}

The mercury is first estimated after the addition of cobalticyanide, as already described.

Draw off all the remainder of the chloroform-dithizone layer after the mercury estimation. (Any interfacial scum should be left.) Add $5 \mathrm{ml}$. chloroform and shake for I5 sec. to remove any remaining dithizone. Allow the solution to stand for some time, during which the contents of the funnel should be gently swirled at intervals to collect together the drops of chloroform adherent to the sides of the funnel. Run off the chloroform layer and discard. Add to the contents of the funnel successively $5 \mathrm{ml}$. citric acid, $2 \mathrm{ml}$. ammonium hydroxide and Io $\mathrm{ml}$. of carbamate, shaking between each addition. Allow to stand 5-10 min. and then add Io $\mathrm{ml}$. chloroform (up to $0.5 \mathrm{mg}$. of copper per litre) or $20 \mathrm{ml}$. of chloroform (up to I.O $\mathrm{mg}$. of copper per litre). Shake for $2 \mathrm{~min}$., allow to settle and run off the required amount of chloroform layer into a I cm. cell. Measure the transmittancy with the Spekker set at I.०O against pure chloroform. Violet filters (Ilford 60I) are used.

\section{Discussion}

The method clearly depends on the inability of the added cobalticyanide to prevent the formation of the yellow complex with the copper reagent when the solution is made alkaline. That complete recovery of the copper was obtained in the presence of cobalticyanide after the addition of ammonia was shown by adding these reagents to solutions of copper sulphate whose copper content had already been determined by the carbamate method; the results are shown in Table X (appropriate 'blank' corrections have been made).

\section{TABLe X}

Total volume extracted $100 \mathrm{ml}$. Concentrations in $\mu \mathrm{g} . / 1$.

Cu present, by
carbamate method

I 24

248

620
$\mathrm{Cu}$ found after cobalticyanide-ammonia

I 24

250

630

\section{TABLE XI}

Total volume extracted $100 \mathrm{ml}$. Concentrations in $\mu \mathrm{g} . / 1$.

\begin{tabular}{|c|c|}
\hline \multicolumn{2}{|c|}{ Copper } \\
\hline Present & Found \\
\hline 500 & 510 \\
\hline 320 & 320 \\
\hline I55 & I 43 \\
\hline 670 & 675 \\
\hline 820 & 810 \\
\hline 995 & 990 \\
\hline
\end{tabular}

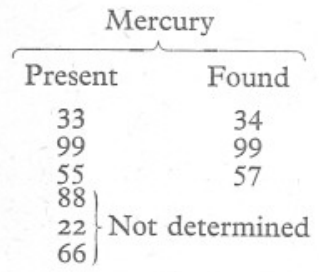


A working curve must be constructed for the $10 \mathrm{ml}$. and the $20 \mathrm{ml}$. volumes of chloroform. The copper solution for this must be taken through the whole procedure, otherwise a considerable error will arise due to the solubility of chloroform in water, for the final extraction is made from a solution saturated with respect to chloroform by the additions involved in the first part of the estimation (mercury). If this is not done an error of some $4 \%$ will be incurred.

Using this combined method, mixtures of copper and mercury were analysed, the amounts present being unknown to the analyst, with the results shown in Table XI.

The author is indebted to the Marine Corrosion Sub-Committee of the Iron and Steel Institute for permission to publish this work and to Professor J. E. Harris for his interest in it.

\section{SUMMARY}

I. A brief survey is given of the methods for the estimation of mercury by means of dithizone.

2. The precautions necessary in mercury estimations are outlined and the stability of dithizone in chloroform solutions shown to be satisfactory.

3. Data are presented on the rate of extraction of copper, from sea-water solutions, at low $p \mathrm{H}$ values with chloroform and carbon tetrachloride solutions of the reagent. Using the former solvent the rate of extraction of copper is shown to be slow, while mercury is rapidly extracted under the same conditions.

4. The use of potassium cobalticyanide in combination with a chloroform solution of dithizone has enabled a method to be developed which eliminates interference of copper in mercury estimations; with the procedure given, mercury in concentrations of I to $55 \mu \mathrm{g} / 1$. may be determined in the presence of copper concentrations up to $6.9 \mathrm{mg} . / 1$.

5. Copper may be determined in the same solution subsequent to the mercury estimation by the use of sodium diethyldithiocarbamate, after the solution has been made alkaline with ammonium hydroxide.

\section{REFERENCES}

Greenleaf, C. A., 1942. Report on copper. Fourn. Ass. Off. Agric. Chem. U.S.A., Vol. 25, p. 266.

HARrIS, J. E., I945. Report of anti-fouling investigations. Fourn. Iron Steel Inst. (in the Press).

HubBard, D. M., I940. The determination of mercury in urine. Ind. Eng. Chem. (Anal. Ed.), Vol. I2, p. 768.

Ketchum, B. H., Ferry, J. D., Redfield, A. C. \& Burns, A. E., I945. Evaluation of antifouling paints by leaching rate determinations. Ind. Eng. Chem., Vol. 37, p. 456.

Laug, E. P. \& Nelson, K. W., 1942. Report on mercury. Fourn. Ass. Off. Agric. Chem. U.S.A., Vol. 25, p. 399.

SANDEll, E. B., I937. Determination of copper, zinc and lead in silicate rocks. Ind. Eng. Chem. (Anal. Ed.), Vol. 9, p. 464.

- I944. Colorimetric Determination of Traces of Metals. New York.

WICHMANN, H. J., I939. Isolation and determination of traces of metals by the dithizone system. Ind. Eng. Chem. (Anal. Ed.), Vol. Ir, p. 66. 